\title{
CRITICALITIES AND POTENTIALITIES OF LOCAL RENEWABLE SOURCES OF ENERGY
}

\author{
LUCA ADAMI ${ }^{1}$, GIACOMO CASTAGNA ${ }^{1}$, ELENA MAGARIL ${ }^{2}$, \\ RAMONA GIUREA ${ }^{3}$, NAVARRO FERRONATO ${ }^{3}$, GIANLUCA RUGGIERI ${ }^{3}$, \\ VINCENZO TORRETTA ${ }^{3}$ \& ELENA CRISTINA RADA ${ }^{1,3}$ \\ ${ }^{1}$ Department of Civil, Environmental and Mechanical Engineering, University of Trento, Italy \\ ${ }^{2}$ Ural Federal University, Department of Environmental Economics, Ekaterinburg, Russia \\ ${ }^{3}$ Insubria University, Department of Theoretical and Applied Science, Varese, Italy
}

\begin{abstract}
In this article, we will discuss about the potential of renewable energies available in a relatively small territorial context, such as municipalities, and the various problems interfering with a full exploitation of said potential. Since the launch of Covenant of Mayors, CoM, in 2008, thousands of local governments committed on volunteer basis in reaching or even exceeding, to the EU targets with regards to climate change and renewable energies for the years to come. Every local government committed to the CoM needs to produce the SEAP (Sustainable Energy Action Plan), which highlights the actions that the government is willing to implement in order to achieve the target set by the CoM (referred either to the 2020 or to the 2030). While studying the local context, many problems of various nature often arise which can be detrimental for the full exploitation of the potential of renewable resources available. This article displays a few examples of local governments located around the world and the problems encountered while writing their SEAP, related to geographical position, types of agricultural, industrial and commercial activities in the area, plants already operative, financial situation of the local government and the population living in the area. The possible areas of intervention include energy efficiency works on public and private buildings, traffic reduction strategies, energy recovery systems applied to factories and industrial plants, solar thermal, photovoltaic and wind power installations, material and energy recovery processes applied to waste management and hydroelectric power installations.
\end{abstract}

Keywords: availability, planning, renewable energy, sustainability, targets.

\section{INTRODUCTION}

Paris agreement on climate change sets a long-term temperature goal of holding the global average temperature increase below $2{ }^{\circ} \mathrm{C}$, possibly limiting the increase to $1.5^{\circ} \mathrm{C}$ above preindustrial levels [1]-[4]. Presently, Paris agreement has been ratified by 178 of 197 Parties at the Convention [5]. In order to achieve these goals, several climate-and energy-related initiatives at different levels has been introduced in the last decade [6]-[9]. The initiative called Covenant of Mayors (CoM) for Climate and Energy was launched in 2008 with the aim to gather local governments to achieving the EU climate and energy targets. On a voluntary base, municipalities or groups of them (called "signatories" by the CoM initiative) can adhere to CoM and sign a declaration stating that they plan to obtain specific targets of $\mathrm{CO}_{2}$ emissions reduction through specific local actions that are described in the SEAP. In particular CoM signatories endorse a shared vision for the long-term target of 2050: accelerating the decarbonisation of their territories, strengthening their capacity to adapt to unavoidable climate change impacts, and allowing their citizens to access secure, sustainable and affordable energy [10]. A short-term target consists in actions to support implementation of the EU 40\% greenhouse gas-reduction target by 2030 and the adoption of a joint approach to tackling mitigation and adaptation to climate change. CoM initiative is part of the world climate change networks such as the Conference of Parties 21, "C40 cities", the ICLEI Local Governments for Sustainability and the Smart Cities Initiative. 
CoM initiative also monitors the progresses of the signatories through two types of Progress Plans: The Monitoring Report, related to the mitigation and adaptation actions adopted, that has to be compiled every two years and the Emission Inventory, related to resilience to climate change, reduction of emission and energy consumption, that has to be compiled every four years. Progress plans consider seven sectors in which specific targets are identified: industry, local electricity production, local heat cold production, municipal buildings equipment facilities, public lighting, residential buildings, tertiary buildings, transport [11]. In the decade 2008-2017, 5960 SEAPs and 1741 progress plans have been published with 2020 targets. The coverage of progress plans is currently below $30 \%$. Only best practices have been traced so far, while local problems SEAPs adoption haven't been described in detail.

In this paper we present 5 cases covering 4 continents describing the geographic characteristics, the economic situation and the origin of the energy locally consumed for each case. Moreover, we focus on the aspects of the environmental sensibility of the population and on a general description of the public environmental programs and of the case studies related to renewable energies in order to point out potentialities and criticalities given by the local renewable sources of renewable energy of the case studies.

\section{CASE STUDIES}

\subsection{La Paz (Bolivia)}

Geographic characteristics. La Paz is located in central Bolivia, near the Andean plateau and the Cordillera. It has a high rate of urbanization (about 1.1\%) [12] and poor political urban planning. The city has a population of about 900,000 inhabitants and it is the seat of the National Government. For this reason, it could be considered one of the most developed Bolivian cities. Its average altitude is about $3,600 \mathrm{~m}$ above sea level. It is located within valleys and rifts, with different slopes, which do not allow the introduction of new infrastructures and factories. Local urban planning management issues are enhancing the need of water and energy, representing a real barrier for improving the sustainability of the city.

Economic situation. La Paz is inserted into a low-middle income country, with about 3,070 USD of gross national yearly income (GNI) per capita and with about $39 \%$ of the population below the national poverty line [13]. Therefore, the differences between rich and poor people are always more visible. The city is one of the most developed within the country due to a tertiary sector well developed. However, the economic sustainability of the city is mainly supported by the national government, in particular regarding the environmental management, which is not covered by municipal taxes, and the costs of the fuels, which are reduced for guaranteeing a low cost of the transportation.

Origin of the energy locally consumed. The support at national level of the fossil fuels is mainly due to amounts produced at national level. Indeed, Bolivia is a producer of methane and petrol, which is used both within the country and exported to neighbour countries, such as Peru, Paraguay, Argentina and Brazil. For this reason, the electricity generated in Bolivia derived mainly by fossil fuels $(60 \%)$, of which $91 \%$ is produced from methane combustion, and for $40 \%$ by hydroelectric power [14]. Therefore, the use of renewable energy is not well developed and encouraged.

Environmental sensibility among the population. As a developing big city, the public awareness about environmental issues is low, due to the lack of public campaigns and the 
introduction of environmental activities. The lack of financial sustainability could not encourage the improvement of the environment, supported only by international NGOs.

Public environmental programs and case studies related to renewable sources of energy. There are not local and national programs related to the use of renewable energies, as well as significant pilot projects related to renewable energy sources. The application of new technologies for the exploitation of other source of energy are only applied in pilot projects, or household level. It is the case of the anaerobic digestion, for the production of bio-methane for cooking, or the application of solar panels for the generation of hot water. However, these technologies are not encouraged at national level. The opportunities and weak points regarding renewable energy sources are reported in Table 1.

\subsection{Ekaterinburg (Russia)}

Geographic characteristics: with a population of 1,48 million inhabitants, Ekaterinburg is located in the eastern side of the Ural Mountains. The city is located on a natural watershed, with the presence of several water bodies in the neighbourhood of the city. There are two lakes in the city. Ekaterinburg's position on the border of Europe and Asia offers opportunities as a centre of cooperation between East and West.

Economic situation. Ekaterinburg is a historical and economic centre of the Urals forming a natural border between Europe and Asia [15]. The city is very rich in minerals and raw materials; main industry branches are heavy machinery and metallurgy. An increasing number of international companies operate their branches and joint ventures here. The city is the administrative, economic and cultural capital of the Urals. Nowadays the city is an important centre of industry, transport, finance, science and culture [16]. Ekaterinburg is one of the largest financial and business centres in Russia. Key industries present are: ferrous and non-ferrous metals, machine engineering and metal processing, energy [17].

Origin of the energy locally consumed. The city's heat and power are supplied by five power stations. However, overall consumption of energy is between 30-40\% higher than in comparable Western European cities. This is coupled with high levels of atmospheric pollution [18]. Electrical energy feeding the city is produced by power plants working on natural gas. Shortfalls are mainly covered by nuclear energy delivered from a power station [19]. Based on available data of the population and total energy demands in the region, energy annual consumption per capita was estimated as 10.5 MWh [20]. A methodology was proposed for including the environment as one of the factors in the regional electrification programs [21].

Environmental sensibility among the population. An emerging attention to renewable energies can be linked with the city, in particular through its candidacy as the hosting city of EXPO-2025 event, on the theme: "Changing the World: Innovations and Better Life for Future". City will develop in the next decade several actions on the topics of energy saving, energy efficiency, power industries including hydro-electric power plants.

Public environmental programs and case studies related to renewable sources of energy. The city is presently investing funds in the development of the Multi-Year Investment Plan for Municipal Environmental Infrastructure, started in 2003 [22] and in specific studies on the quality of water from sources of decentralized water supply [23], use of wood in the "Green Project" to enhance the green endowment of the city [24] and as an energy resource [25]. Renewable energy sources use for sustainable development of the city was also analysed [26] as well as fees as a source for the environmental development of the city [27]. The increased quality of life is related to the environmental development of the city [28]. 
Table 1: Critical issues in the potential exploitation of renewable sources in La Paz.

\begin{tabular}{|c|c|c|}
\hline Source type & Potential exploitation & Criticalities / Opportunities \\
\hline $\begin{array}{l}\text { Livestock } \\
\text { waste }\end{array}$ & $\begin{array}{l}\text { The city and the areas around } \\
\text { are not a source of significant } \\
\text { livestock waste flows. So, no } \\
\text { specific waste treatment plant } \\
\text { are implemented. }\end{array}$ & - \\
\hline $\begin{array}{l}\text { Sewage } \\
\text { sludge }\end{array}$ & $\begin{array}{l}\text { No wastewater treatment is } \\
\text { present (even decentralised) } \\
\text { thus no sewage sludge is } \\
\text { generated }\end{array}$ & $\begin{array}{l}\text { The expected development of a strategy for } \\
\text { wastewater treatment in the city will change the } \\
\text { scenario towards the generation of sewage sludge. }\end{array}$ \\
\hline $\begin{array}{l}\text { Organic } \\
\text { fraction of } \\
\text { municipal } \\
\text { solid waste } \\
\text { (OFMSW) } \\
\text { and green } \\
\text { waste }\end{array}$ & $\begin{array}{l}\text { The quantities of waste } \\
\text { generated within the city are } \\
\text { significant, although not } \\
\text { treated; they are disposed of } \\
\text { into a sanitary landfill. }\end{array}$ & $\begin{array}{l}\text { There are many management issues regarding } \\
\text { OFMSW management. Only a few pilot projects } \\
\text { are introduced for the treatment of such streams. } \\
\text { Moreover, the application of anaerobic digestion is } \\
\text { very difficult at an environmental and } \\
\text { technological point of view. }\end{array}$ \\
\hline $\begin{array}{l}\text { Biogas from } \\
\text { landfill }\end{array}$ & $\begin{array}{l}\text { The sanitary landfill is a source } \\
\text { of biogas which is not } \\
\text { exploited. Moreover, is } \\
\text { production is not monitored and } \\
\text { well managed. }\end{array}$ & $\begin{array}{l}\text { The landfill biogas could be considered an option } \\
\text { for the generation of electric energy. However, it is } \\
\text { not encouraged, and the investment required could } \\
\text { represent a barrier in this context. }\end{array}$ \\
\hline $\begin{array}{l}\text { Surface water } \\
\text { bodies }\end{array}$ & $\begin{array}{l}\text { Hydropower plants are } \\
\text { introduced in the country. } \\
\text { However, the city is mainly } \\
\text { provided by electric energy } \\
\text { generated by fossil fuels. }\end{array}$ & $\begin{array}{l}\text { The morphology of the city could be exploited for } \\
\text { the implementation of hydropower plants. } \\
\text { However, specific investments are required, } \\
\text { although the policy of the country is mainly } \\
\text { focused on the exploitation of fossil fuels. }\end{array}$ \\
\hline Photovoltaic & $\begin{array}{l}\text { It is not a technology well } \\
\text { developed in Bolivia, while La } \\
\text { Paz could not be considered as } \\
\text { the best area for its application } \\
\text { due to the lack of space for the } \\
\text { building of photovoltaic parks. }\end{array}$ & $\begin{array}{l}\text { The particular characteristics of the area of La Paz } \\
\text { make necessary the development of a specific } \\
\text { photovoltaic panel. However, it could be applied at } \\
\text { household level, and the solar incidence could be } \\
\text { advantageous for its application. }\end{array}$ \\
\hline Solar thermal & $\begin{array}{l}\text { This technology is implemented } \\
\text { at household level. However, it } \\
\text { is not introduced within the city, } \\
\text { since its main application could } \\
\text { be found in rural areas and } \\
\text { within boundaries of the city. }\end{array}$ & $\begin{array}{l}\text { This technology could be of interest for the area, } \\
\text { although it could not be considered as the main } \\
\text { solution for solving the energy demand. }\end{array}$ \\
\hline Wood (local) & $\begin{array}{l}\text { Wood and other biomasses, } \\
\text { such as agricultural waste, are } \\
\text { mainly used in the external } \\
\text { areas of the city and in the rural } \\
\text { areas. The centre of La Paz is } \\
\text { not organized for its use. }\end{array}$ & $\begin{array}{l}\text { The combustion of biomass is a big issue as regard } \\
\text { indoor pollution in rural areas, while in La Paz is } \\
\text { not applied. This could be considered an advantage } \\
\text { in an environmental point of view, since the } \\
\text { combustion of methane, instead of biomass, allows } \\
\text { reducing the generation of } \mathrm{NO}_{2} \text { and } \mathrm{PM}_{10} \text {. }\end{array}$ \\
\hline
\end{tabular}




\subsection{Sibiu (Romania)}

Geographic characteristics. Sibiu County is a county (județ) of Romania, in the historical region of Transylvania, with the capital city Sibiu. The county of Sibiu is situated in the centre of Romania, at $280 \mathrm{~km}$ away from Bucharest, the capital of the country. It is a county of middle size, with a total area of $5.433 \mathrm{~km}^{2}$ [29], [30]. The city is in the temperate continental zone, with thermal influences due to the depression area and the mountains that surround it in the south and south-west [31].

Economic situation. The main economic branches with a high share in the economy of the municipality are: production of components for the automotive industry, logistics and logistics packaging, food industry, textiles, services and production craft. Sibiu is an important economic hub for Romania, with a high rate of foreign investments [32]. These activities add to the services that support the cultural tourism sector, based on the existing heritage on the cultural agenda and the reputation of the European Capital of Culture in 2007. From the perspective of the dynamics of economic activity, the financial crisis has affected the number of firms; however, the unemployment rate remains low [33]. In the Forbes Best Cities top 2015 - 40 best business cities, Sibiu ranks 13th. Sibiu is already ranked 5 th at national level in terms of GDP per capita and 6th in terms of net average wage. The industrial profile is given of the food industry, the textile apparel industry, wood processing, building materials and the automotive industry (car parts and subassemblies). Tourism is also an important sector, based on natural and cultural potential the region. A factor that plays an important role in the economy of the city is tourism, which has been increasing at a steady rate since 2007. Sibiu is one of the most important cultural and economic centres of Romania and was designated the European Capital of Culture for the year 2007, along with the city of Luxembourg [34]. Formerly the centre of the Transylvanian Saxons, the old city of Sibiu was ranked as "Europe's 8th-most idyllic place to live" by Forbes in 2008 [35]. In 2019 Sibiu County will be awarded the title of Region of Gastronomy, alongside Greece's South Aegean region [36]. The factors making the economic development of the county are the geographic position, natural resources and handicraft tradition in processing the county's resources.

Origin of the energy locally consumed. 1. Thermal energy supply: In the city of Sibiu, natural gas is used to provide thermal energy. Heating of buildings is done either in a centralized system or using individual boilers or stoves. At the level of the city of Sibiu, natural gas distribution is provided by S.C. E-On. Gaz Distribuţie România S.A. Under the Sustainable Energy Action Plan of the City of Sibiu, 2014 the gas distribution network totals $420 \mathrm{~km}$, the total number of branching at the level of the City of Sibiu being 19,802. The technical state of the gas distribution network is good in $90 \%$, the remaining $10 \%$ being rehabilitated. [37] 2. Electricity supply: On the territory of Sibiu Municipality, the electricity distribution to the consumers is ensured by the Sibiu Electricity Distribution Branch belonging to S.C. Electrica SA - Transylvania South Branch. Supply of electricity on the regulated market is mainly done by S.C. Electrica S.A., as the default supplier. At the local level, the power supply is made by means of five transformer stations, connected to the National Power Grid, with a total capacity of $190 \mathrm{kV}$. As far as street lighting is concerned, it is carried out with 7,852 sodium vapour lamps with nominal power between $70 \mathrm{~W}$ and $250 \mathrm{~W}$ respectively with an installed power of $1,356.28 \mathrm{~kW}$. The analysis of lighting sources carried out for the elaboration of the Sustainable Energy Action Plan of the City of Sibiu in 2014 [37] reveals that about $42 \%$ of them have a small wear degree, the remainder being of high and medium wear. Thus, the replacement of high-wear sodium-vapour lamps is a consideration with high-performance luminaires with low consumption electricity. The city 
of Sibiu is supplied with electricity from the National Power System through 5 transformer power stations.

Environmental sensibility among the population. In the current context, taking into account climate change and global warming, nature is receiving ever greater attention. From the primary sector (agriculture) to the secondary sector (industry, production) or tertiary (services), human activities extract their resources from nature. Thus, it is essential that midterm and long-term planning take account of the environmental impact. Being responsible, in the current understanding, refers to aspects of lifestyle, sustainable development, and being "green". This attitude presupposes the desire of members of the community to make a positive contribution, aware of the impact that human settlements have on the environment. A responsible company uses the resources that it has at its disposal, without creating any disadvantages for future generations [38].

Public environmental programs and case studies related to renewable sources of energy. Romania is Member States of the European Union, therefore EU law affects direct or indirect the national [39], [40] and regional law [41]-[44] and becomes part of the legal system. The European Union is a source of law for Sibiu city. In Sibiu the actions are focused on the transpose of European regulations in internal legislation and on the assurance of implementation conditions to European requests. Furthermore, in Romania the legislative background was improved by adopting the lows regarding the renewable energy chapter.

\subsection{Oppeano (Italy)}

Geographic characteristics. The Municipality of Oppeano is set in the southern part of the Province of Verona, in northern Italy. In this Municipality live 9,972 inhabitants, scattered among the center of the Municipality and the various hamlets (Cà degli Oppi, Vallese, Mazzantica, Villafontanta and Ponte Ebreo) in an area $49.95 \mathrm{~km}^{2}$ wide. The municipal territory is crossed by three creeks: Bussè, Piganzo and Menago. The climate of Oppeano can be described as Cfa according to the Köppen-Geiger climate classification system; in Italy the Municipality is identified with the climatic zone E and has an HDD value of 2,340.

Economic situation. This Municipality has a very developed agricultural sector and its most iconic product is Vialone Nano Veronese, a renowned variety of rice. Very developed is also the breeding sector, with numerous piggeries, poultry and cow farms scattered around the territory. The presence of the industrial and service sectors is strong as well, with a multinational clothing company that have a warehouse in the municipal territory and the recently built national logistics centre of a discount supermarket chain. Potential renewable energy resources available in the Municipality of Oppeano are listed in Table 2. The scenario described in Table 2 is very promising at first look: Municipality of Oppeano has plenty of potential renewable energy resources coming from numerous production activities and environmental plants. However, with further study and insights of the situation, the possibilities of implementing a strategy to produce renewable energy starting from the resources present in the municipal area turned out to be worse than expected. The problems arose and the difficulties encountered while planning the municipal strategy for achieving the CoM 2020 emission targets are shown in Table 3. Table 3 describes the difficulties encountered to set up an efficient management strategy for the exploitation of renewable energy resources with the aim to achieve emission reduction targets.

Origin of the energy locally consumed. 1 . Thermal energy supply: in the Municipality of Oppeano are used $9.04 \mathrm{~m}^{3} / \mathrm{inh}$. of natural gas per year for the heating of the public buildings, and the trend shows that the quantity is decreasing (15.1 m3/inh. in year 2011). For what concerns the private buildings sector, in Oppeano are used 4,150,362 $\mathrm{m}^{3} /$ year of 
Table 2: Potential renewable energy resources available.

\begin{tabular}{|c|c|c|}
\hline $\begin{array}{l}\text { Resource } \\
\text { type }\end{array}$ & Quantity & Description \\
\hline \multirow{3}{*}{$\begin{array}{l}\text { Zootechnical } \\
\text { slurry }\end{array}$} & Poultry: 365,192 & - \\
\hline & Pigs: 8,520 & - \\
\hline & Cows: 6,999 & - \\
\hline Sewage sludge & $226 \mathrm{kgTDS} / \mathrm{d}$ & $\begin{array}{l}\text { Referred to the soon to be built sewage treatment plant, } \\
\text { designed for } 8,000 \mathrm{PE} \text {. }\end{array}$ \\
\hline OFMSW & 1,012 t/year & $\begin{array}{l}\text { The available quantity raises to } 6,500 \text { t/year when } \\
\text { considering the whole competence area of the local waste } \\
\text { manager, which includes nearby municipalities. The overall } \\
\text { quality of the OFMSW collected is high. }\end{array}$ \\
\hline Green Waste & $637 \mathrm{t} /$ year & - \\
\hline $\begin{array}{l}\text { Other } \\
\text { biomasses }\end{array}$ & Not specified & $\begin{array}{l}\text { In the Municipality there are various types of crops: corn, } \\
\text { orchards, sunflower, rice, tobacco and soy. The scraps } \\
\text { coming from the agricultural sector could be used to } \\
\text { produce green energy, for example in anaerobic co- } \\
\text { digestion plants. }\end{array}$ \\
\hline PV & $\begin{array}{l}15 \text { public } \\
\text { buildings }\end{array}$ & \multirow{2}{*}{$\begin{array}{l}\text { Annual global radiation on horizontal surface is } 5.090 \\
\mathrm{MJ} / \mathrm{m}^{2} \text {. When considering also private buildings, such as } \\
\text { houses and industrial sheds, the quantity can increase up to } \\
\text { three orders of magnitude. }\end{array}$} \\
\hline Solar thermal & $\begin{array}{l}15 \text { public } \\
\text { buildings }\end{array}$ & \\
\hline $\begin{array}{l}\text { Surface water } \\
\text { bodies }\end{array}$ & 3 hydraulic jumps & $\begin{array}{l}\text { Located at Villafontana (Menago river), Feniletto } \\
\text { (Irrigation channel), Villa Anti (Piganzo river). }\end{array}$ \\
\hline Geothermal & - & \multirow{2}{*}{$\begin{array}{l}\text { The Municipality area is of no interest with regards to these } \\
\text { types of energy, according to the provincial energy } \\
\text { management plans. }\end{array}$} \\
\hline Eolic & - & \\
\hline
\end{tabular}

natural gas, 232,932 1/year of gas oil, 338,237 1/year of LPG and 1,780,620 kg/year of biomass (wood). In Oppeano there are no district heating networks nor geothermal plants active. 2. Electricity supply: the electricity consumption for public streets illumination in the Municipality of Oppeano is $937,757 \mathrm{kWh} /$ year and the trend is decreasing $(1,221,517$ $\mathrm{kWh} /$ year in 2011).

The local government is currently financing the complete substitution of the traditional sodium-vapour lamps with LED lamps. The electricity consumption of public and private buildings is $11.884 .125 \mathrm{kWh} /$ year. Currently in the Municipality there are $186 \mathrm{PV}$ plants active, accounting for a total power of $6.300,09 \mathrm{~kW}$. The local government is evaluating to implement more PV plants on public buildings covers. In Oppeano there are no active winds farms nor hydroelectric plants.

Environmental sensibility among the population. Currently most of the Italian population is really concerned about environmental thematics, and terms like sustainability, green economy, climate change and renewables are ever recurrent in the political, scientific and public debate. With regards to this specific case, it is useful to look at the data available for the energetic certification of the residential buildings in Oppeano [45], which demonstrate the progressive increment of residential buildings certified with higher energetic classes. Moreover, with regards to the transportation sector, it should be noticed that the number of electric and hybrid cars in Veneto region is increasing year by year (6470 hybrid cars and 213 electric cars in 2015 and 12535 hybrid cars and 408 electric cars in 2017) thus confirming again the importance of environmental topics among the population. 
Table 3: Critical issues encountered in the exploitation of available renewable resources for the municipality of Oppeano (Italy).

\begin{tabular}{|c|c|c|}
\hline Resource type & Hypothesized exploitation & Issues \\
\hline $\begin{array}{l}\text { Zootechnical } \\
\text { slurry }\end{array}$ & \multirow{3}{*}{$\begin{array}{l}\text { Anaerobic digestion to } \\
\text { produce biogas/biomethane. }\end{array}$} & $\begin{array}{l}\text { In the Municipality there is a recently built } \\
\text { nitro-denitro plant designed for the pre- } \\
\text { treatment of zootechnical slurry that needs } \\
\text { to be feed. This economically prevents the } \\
\text { use of the resource for the } \\
\text { biogas/biomethane production. }\end{array}$ \\
\hline Sewage sludge & & $\begin{array}{l}\text { The Municipality recently approved the } \\
\text { project of the new sewage treatment plant, } \\
\text { which is designed to operate in prolonged } \\
\text { aeration conditions. The resulting sewage } \\
\text { sludge is therefore not suitable as input in } \\
\text { an anaerobic digestion process. }\end{array}$ \\
\hline $\begin{array}{l}\text { OFMSW and } \\
\text { green waste }\end{array}$ & & $\begin{array}{l}\text { The availability of OFMSW in the } \\
\text { municipality is not sufficient to feed a } \\
\text { traditional anaerobic digestion plant under } \\
\text { economically favorable conditions, even } \\
\text { when considering the total OFMSW } \\
\text { collected by ESA-com, the local waste } \\
\text { management company. }\end{array}$ \\
\hline $\begin{array}{l}\text { Surface water } \\
\text { bodies }\end{array}$ & $\begin{array}{l}\text { Installation of hydraulic } \\
\text { turbines to produce } \\
\text { hydroelectric energy. }\end{array}$ & $\begin{array}{l}\text { The jump located at Villafontana is the most } \\
\text { interesting with } 1 \mathrm{~m} \text { of height and an } \\
\text { average flow of } 1 \div 2 \mathrm{~m}^{3} / \mathrm{s} \text {. It could host } \\
\text { micro turbines of about } 20 \div 30 \mathrm{~kW} \text {. } \\
\text { However, the Reclamation Consortium of } \\
\text { Verona expressed a negative opinion about } \\
\text { its exploitation because of hydrogeological } \\
\text { instability of the area and the resulting costs } \\
\text { to be incurred for additional maintenance. } \\
\text { The other two hydraulic jumps identified in } \\
\text { the Municipality area are too small to be } \\
\text { exploited under economically favourable } \\
\text { conditions. }\end{array}$ \\
\hline \multirow[t]{2}{*}{ PV } & $\begin{array}{l}\text { Installation of PV panels on } \\
\text { the roofs of municipal } \\
\text { buildings to produce electric } \\
\text { energy. }\end{array}$ & No issues observed. \\
\hline & $\begin{array}{l}\text { PV noise barrier installed on } \\
\text { the SS } 434 \text { Transpolesana } \\
\text { road }(867 \mathrm{~kW}) \text {. }\end{array}$ & $\begin{array}{l}\text { This PV plant is not working now. There is } \\
\text { a legal dispute in progress caused by the } \\
\text { bankruptcy of the company that installed it. }\end{array}$ \\
\hline Solar thermal & $\begin{array}{l}\text { Installation of solar thermal } \\
\text { panels on the roofs of } \\
\text { municipal buildings to } \\
\text { produce hot water. }\end{array}$ & $\begin{array}{l}\text { No issues observed. However, it should be } \\
\text { noted that for a public building the optimal } \\
\text { solar exploitation is PV, since schools and } \\
\text { city halls are uninhabited for the most part } \\
\text { of the day and they need less hot water than } \\
\text { the typical residential building does. }\end{array}$ \\
\hline Other biomasses & $\begin{array}{l}\text { Anaerobic co-digestion to } \\
\text { produce biogas/biomethane. }\end{array}$ & $\begin{array}{l}\text { The problems related to the scale factor } \\
\text { mentioned above for the OFMSW stay } \\
\text { relevant in this case too. }\end{array}$ \\
\hline
\end{tabular}


Public environmental programs and case studies related to renewable sources of energy. An unconventional solution to this problem, which partially address the necessity of the Municipality to reduce $\mathrm{CO}_{2}$ emissions without compromising the operation of the plants already present, revolves around the thermochemical hydrolysis process, hereby briefly described. The OFMSW provided by ESA-com $(6,500 \mathrm{t} / \mathrm{year})$ should be used to run an anaerobic digestion plant based on the thermochemical hydrolysis process.

This process includes a pre-treatment of the OFMSW that separate the high COD, readily biodegradable liquid fraction from the low COD, slowly biodegradable semi-solid fraction. The liquid fraction is digested in a small anaerobic reactor with lower HRT than traditional ones, while the semi-solid fraction can be sent to composting with no further treatment.

This solution is compatible with the small quantity of MSW available because: (I) the digested material can be treated in the already active nitro-denitro plant with no further costs (agreement between the Municipality and the farm); (II) the exhausted air coming from the anaerobic digestion plant can be sent to the activated sludge tank of the municipal sewage treatment plant, saving here also on the treatment costs and (III) the semi-solid fraction of the OFMSW can be sent to composting at a lower cost than normal, since a part of the COD has been extracted during the thermochemical hydrolysis process.

\subsection{Tanzania}

Geographic characteristics. The local administration in Tanzania is based on a multilevel organization. In rural Tanzania the village council elects a chairperson that represent the village in the Ward. The Ward is a democratic subdivision that includes different villages (or different streets in urban territories). A District includes different Wards. District councils coordinate the activities of the township authorities and village councils.

Economic situation. The village and township councils have financial responsibility over the funds they receive from the national government. Mainland Tanzania (i.e. excluding Zanzibar) has 138 urban districts including 630 wards and 133 rural district which include 2682 villages. The estimated population is around 50 million in 2017 . The village and township councils should also formulate plans for their areas. Plans are developed in association with formally established bodies and must secure district approval. The crucial actor in planning activities is the Ward Development Committee (WDC). The WDC coordinates development plans and social service plans, supervises project implementation and service delivery activities, and is an intermediary for discussing initiatives arising from the sub-ward levels and development plans from the higher tier local authorities.

Origin of the energy locally consumed. Tanzania's energy supply depends mainly on biomass. Since $85-90 \%$ of the population is not connected to the electricity grid, the overwhelming majority of households use wood and charcoal for cooking. As a total, biomass makes up close to $90 \%$ of the total primary energy consumption in Tanzania. Unfortunately, this leads to the deforestation of $100,000 \mathrm{~h}$ per year, of which only about a quarter is reforested. Other energy sources are petroleum, which makes up $7.8 \%$ of total primary energy consumption, natural gas $(2.4 \%)$, hydropower $(1.2 \%)$ and coal/peat $(0.3 \%)$. About 6.6 percent of primary energy needs to be imported, primarily from Uganda ( $8 \mathrm{MW})$ and Zambia (5 MW) (International Energy Agency).

Environmental sensibility among the population. The Tanzanian government has joined the Sustainable Energy for All Initiative (SEforALL) launched in 2011 by the United Nation Secretary-General Ban Ki Moon. In 2015, the Ministry of Energy and Minerals has published an Action Agenda [46] that defines the following national targets for 2030 (compared with 2012 as a baseline year): (1) At least $75 \%$ of population with electricity 
access; (2) At least 75\% of population with access to modern cooking solutions; (3) Rate of improvement in energy intensity at least $-2.6 \%$ per year; (4) At least $50 \%$ of electricity and $10 \%$ of heat from renewable energy sources (including off-grid generation). The Action Agenda lists all the existing plans active in Tanzania in the fields of Energy Access, Renewable Energy and Energy Efficiency. Seventeen plans address the issue of electricity connections, five plans address the issue of grid development, four plans work on the clean cooking or cook-stoves issue. There are at least six plans or strategies in the field of renewable energies and at least seven plans or strategies in the field of energy efficiency.

Public environmental programs and case studies related to renewable sources of energy. Given this rather complex framework, it is possible to highlight that the main barrier to develop effective and comprehensive planning and define adequate funding is the weak communication mechanism between local government authorities and the national government. The activities on energy planning, implementation and monitoring are developed with limited or no intervention from regional authorities and other local stakeholders. The lack of communication is a big problem under different points of view: (I) the central government risks to fail to understand the situation and needs at regional level; (II) the strategies developed may have better success when including and empowering final beneficiaries and (III) if we put the specific targets in perspective of the 2030 Agenda, energy is a possible tool to the full empowerment of women: a single approach may benefit Sustainable Development Goals targets 7 and 5.

\section{CONCLUSIONS AND RECOMMENDATIONS}

Uttermost weather, increased temperatures, melting glaciers are obvious signs that climate change is happening. Therefore, even in a relatively small territorial context, such as municipalities, towns and regions play an important role in the actions against global warming - one of the significant challenges nowadays- taking into consideration their task regarding spatial planning, energy and transport.

As of today, thousands of local and regional governments have joined the Covenant of Mayors. In this context, this paper presents the status of a few examples of governments located around the world and the problems that are coming across while writing their SEAP, related to geographic characteristics, economic situation, origin of the energy locally consumed, environmental sensibility among the population and some public environmental programs and case studies related to renewable sources of energy. All of these are presented with the aim of underlining the potentialities and criticalities elaborated by the local sources of renewable energy encountered in those case studies.

\section{ACKNOWLEDGEMENT}

This research was supported by the Municipality of Oppeano (Italy) and by Act 211 Government of the Russian Federation, contract № 02.A03.21.0006.

\section{REFERENCES}

[1] Rogelj, J. et al., Paris Agreement climate proposals need a boost to keep warming well below $2{ }^{\circ}$ C. Nature, 534(7609), pp. 631-639, 2016. DOI: 10.1038/nature18307.

[2] Schleussner, C.-F. et al., Differential climate impacts for policy-relevant limits to global warming: The case of $1.5^{\circ} \mathrm{C}$ and $2^{\circ} \mathrm{C}$. Earth System Dynamics, 7(2), pp. 327351, 2016. DOI: 10.5194/esd-7-327-2016.

[3] Schleussner, C.-F. et al., Science and policy characteristics of the Paris Agreement temperature goal. Nature Climate Change, 6(9), pp. 827-835, 2016. DOI: 10.1038/nclimate3096. 
[4] Hulme, M., $1.5^{\circ} \mathrm{C}$ and climate research after the Paris Agreement. Nature Climate Change, 6(3), pp. 222-224, 2016. DOI: 10.1038/nclimate2939.

[5] United Nations Climate Change, Paris Agreement: Status of Ratification. https://unfccc.int/process/the-paris-agreement/status-of-ratification. Accessed on: 30 Mar. 2018.

[6] Lombardi, M., Pazienza, P. \& Rana, R., The EU environmental-energy policy for urban areas: The Covenant of Mayors, the ELENA program and the role of ESCos. Energy Policy, 93, pp. 33-40, 2016. DOI: 10.1016/j.enpol.2016.02.040.

[7] Cosmi, C., Salvia, M., Di Leo, S., Pietrapertosa, F. \& Loperte, S., Interregional cooperation as a key tool for the achievement of strategic-energy and climate targets: The experience of the interreg IVC RENERGY and SEE RE-SEEties Projects. Smart and Sustainable Planning for Cities and Regions. SSPCR 2015. Green Energy and Technology, eds A. Bisello, D. Vettorato, R. Stephens \& P. Elisei, pp. 335-352, 2017.

[8] Gargiulo, M. et al., An integrated planning framework for the development of sustainable and resilient cities: the case of the InSMART project. Procedia Engineering, pp. 444-453, 2017.

[9] Bertoldi, P., Kona, A., Rivas, S. \& Dallemand, J.F., Towards a global comprehensive and transparent framework for cities and local governments enabling an effective contribution to the Paris climate agreement. Current Opinion in Environmental Sustainability, 30, pp. 67-74, 2018. DOI: 10.1016/j.cosust.2018.03.009.

[10] Covenant of Majors, Signatories' vision. www.covenantofmayors.eu /about/covenantinitiative/objectives-and-scope.html. Accessed on: 30 Mar. 2018.

[11] Delponte, I., Pittaluga, I. \& Schenone, C., Monitoring and evaluation of sustainable energy action plan: Practice and perspective. Energy Policy, 100, pp. 9-17, 2017. DOI: 10.1016/j.enpol.2016.10.003.

[12] INE (2012) Características de Población y Vivienda, Censo Nacional de Población y Vivienda, Bolivia. 10. (In Spanish). www.indec.gob.ar/ftp/cuadros/poblacion/ censo2010 tomo1.pdf. Accessed on: Jun. 2018.

[13] World Bank Bolivia, The World Bank data. https://data.worldbank.org/ country/bolivia. Accessed on: Jun. 2018.

[14] Ministerio de Hidrocarburos y Energía, Memoria Institutional. Estado Plurinacional de Bolivia (In Spanish). https://es.scribd.com/document/240107124/MemoriaInstitucional-2012. Accessed on: Jun. 2018.

[15] Nifantova, R.V., Makarova, M.N. \& Kosmin, I.F. Ekaterinburg on the demographic map of Russia: Facts and prospects. Economy of Region, 4, pp. 52-59, 2010. DOI: 10.17059/2010-4-5.

[16] Economics of Russian cities and urban agglomeration, Institute for Urban Economics. www.urbaneconomics.ru/centr-obshchestvennyh-svyazey/news/reyting-stolichnyhgorodov-rossii-ot-fonda-institut-ekonomiki\# ftn1. Accessed on: 12 Mar. 2018.

[17] Russian Union of Exibition and Fairs, RUEF Exibition Centres. http://ruef.ru/userfiles/ ExhibitionCentresEn2016.pdf. Accessed on: 15 Mar. 2018.

[18] European Commission, TACIS Energy Centre opened in Ekaterinburg. https://cordis.europa.eu/news/rcn/4100_en.html. Accessed on: 30 Mar. 2018.

[19] Karpova, A. \& Tredler, I., Ekaterinburg: A Power Efficient City, Siemens: Moscow, pp. 12-18, 2010.

[20] http://sverdl.gks.ru/wps/wcm/connect/rosstat_ts/sverdl/ru/statistics/sverdlStat/. Accessed on: 5 Mar. 2018. 
[21] Gitelman, L.D., Gitelman, L.M. \& Kozhevnikov, M.V., Factoring environment into electrification management in a region. International Journal of Sustainable Development and Planning, 13(4), pp 707-717, 2018.

[22] Multi-Year Investment Plan for Municipal Environmental Infrastructure in Ekaterinburg, Russia. www.oecd.org/russia/multi-yearinvestmentplanformunicipal environmentalinfrastructureinekaterinburgrussia.htm. Accessed on: 30 Mar. 2018.

[23] Konshina, L.G., The assessment of the quality of water from sources of decentralized water supply of Ekaterinburg and surrounding areas. Gigiena I sanitariia, 95(5), pp. 413-416, 2016.

[24] Damary, R., Pryadilina, N., Zalesov, S. \& Opletaev, A., Outdoor wooden furniture as a component of an overall municipal project: "Green city", 28th International Conference on Wood Science and Technology, ICWST 2017: Implementation of Wood Science in Woodworking Sector, 133147, pp. 237-242, 2017.

[25] Khudyakova, G.I., Danilova, D.A. \& Khasanov, R.R., The use of urban wood waste as an energy resource. IOP Conference Series. Earth and Environmental Science, 72(1), p. 012026, 2017. DOI: 10.1088/1755-1315/72/1/012026.

[26] Volkov, A. \& Aristova, A., Opportunity and prospect analysis of RES utilization for sustainable development of Ekaterinburg city in Russia. IOP Conference Series: Earth and Environmental Science, 72(1), 012024, 2017. DOI: 10.1088/17551315/72/1/012024.

[27] Bystrova, T. \& Larionova, V., Fee development as a tool for the integrated formation of the urban environment, international multidisciplinary scientific geoconference surveying geology and mining ecology management. SGEM, 3, pp. 239-246, 2016.

[28] Lavrikova, Y., Akberdina, V. \& Mezentseva, E., Strategic guidelines of a megalopolis's development: New industrialization and ecological tension. IOP Conference Series: Earth and Environmental Science, 72(1), 012011, 2017. DOI: 10.1088/1755-1315/72/1/012011.

[29] Sibiu Municipality. www.sibiu.ro/index.php/sibiu/prezentare. Accessed on: 1 Apr. 2018.

[30] Sibiu County Tourism Association. www.sibiu-turism.ro/About-us.aspx. Accessed on: 1 Apr. 2018.

[31] Ogimet CLIMAT summary for 15260: Sibiu (Romania)-Section 2: Monthly Normals. CLIMAT monthly weather summaries. Accessed on: 25 Jun. 2017.

[32] Chamber of Commerce, Industry and Agriculture of Sibiu. www.cciasb.ro/. Accessed on: 25 Jun. 2017.

[33] Strategia Integrată de Dezvoltare Urbană Durabilă a Municipiului Sibiu 2023. www.sibiu.ro/new/pdf/SIDU\%20Sibiu\%202017\%2005\%2022_small.pdf. 2017.

[34] Sibiu Cultural Capital Website. http://sibiu2007.ro. Accessed on: 1 May 2018.

[35] Beckett, E. \& Olson, P., In Pictures: Europe's Most Idyllic Places to Live, Forbes. www.forbes.com/2008/11/18/europe-homes-dollar-forbeslife-cx_po_1118realestate_ slide_4.html. Accessed on: 13 Feb. 2018.

[36] International Institute of Gastronomy, Culture, Arts and Tourism (IGCAT), European Region of Gastronomy. www.europeanregionofgastronomy.org/platform/sibiu-2019/. Accessed on: 13 Feb. 2018.

[37] SE1: Sustainable Energy Action Plan of the City of Sibiu, 2014. www.sibiu.ro/ro2/ paed/memoriu_anexe_PAED-SIBIU_ONLINE_final.pdf. Accessed on: 13 Feb. 2018.

[38] SE3: Strategia de Adaptare la Schimbările Climatice a Municipiului Sibiu. www.sibiu.ro/new/pdf/SASC+_PASC_Sibiu_final_(1).pdf. Accessed on: 13 Feb. 2018. 
[39] Indexul Societăţii Durabile ISD-România-2008. www.anpm.ro/anpm_resources/ migrated_content/uploads/9590_3918_Index\%20National\%20SD\%20Romania\%202 008.pdf. Accessed on: 13 Feb. 2018.

[40] Strategia Naţională pentru Dezvoltare Durabilă a României Orizonturi 2013-20202030 (National strategy for sustainable development of Romania horizons). www.anpm.ro/anpm_resources/migrated_content/uploads/9347_sndd.pdf. Accessed on: 13 Feb. 2018.

[41] Strategia Integrată de Dezvoltare Urbană Durabilă a Municipiului, Sibiu 2023 (Integrated Strategy for Urban Development of the Municipality), Publication year 2017. www.sibiu.ro/new/pdf/SIDU\%20Sibiu\%202017\%2005\%2022_small.pdf. Accessed on: 13 Feb. 2018.

[42] Planul de Acţiune pentru Energie Durabilă Municipiului Sibiu, 2014 (Action Plan for Sustainable Energy). www.sibiu.ro/ro2/paed/memoriu_anexe_PAED-SIBIU_ ONLINE_final.pdf. Accessed on: 13 Feb. 2018.

[43] Strategia privind Adaptarea la Schimbările Climatice în Municipiul Sibiu (Strategy for the adaptation of climatic changes in the Municipality). www.sibiu.ro/new/pdf/ SASC+_PASC_Sibiu_final_(1).pdf. Accessed on: 13 Feb. 2018.

[44] PROGRAMUL OPERAȚIONAL REGIONAL, POR Axa prioritară 3. http://regioadrcentru.ro/axa-prioritara-3-1-sprijinirea-eficientei-energetice-gestionariiinteligente-energiei-si-utilizarii-energiei-din-surse-regenerabile-infrastructurilepublice-inclusiv-cladirile-publice/. Accessed on: 13 Feb. 2018.

[45] Energy levels of buildings in Oppeano. https://venet-energia-edifici. regione.veneto.it/VeNet/statistiche.php. Accessed on: 13 Feb. 2018.

[46] Tanzania's SeforALL Action Agenda, December 2015. www.seforall.org/sites/ default/files/TANZANIA_AA-Final.pdf. Accessed on: 30 Mar. 2018. 